\title{
Locus of control of school teachers
}

\author{
Bhumika Achhnani $^{1^{*}}$, Amarin Amareliya ${ }^{2}$ \\ ${ }^{\mathbf{1}}$ Associate Professor, ${ }^{2}$ Student (MBA), Christ Institute of Management Rajkot, Gujarat, India
}

*Corresponding Author: Bhumika Achhnani

Email: sunitabalwani@gmail.com

\begin{abstract}
There are people in this world who feel that they are in charge of everything happening in their life and we also have people who believe that nothing in their life is under their control. And then we also have so many people in between, also some people who believe that either luck or the other people around them are in charge of their lives. This is the concept of locus of control. The education ind ustry as a whole is going through so many changes, with smart classrooms to even smarter kids in schools. Under this background the level of control felt by teachers' w.r.t. their work and lives in general plays a significant role in deciding what actions they are likely to take in order to change the world around them. The current study focuses on exploring the Locus of Control held by teachers in pre-primary and primary section of Guajarati and English medium schools of Rajkot city. The study focuses on analyzing the relationship between different aspects of Locus of Control and age of teachers, it also focuses on finding out if there are any differences in internal, external and chance Locus of Control of teachers' w.r.t. marital status and educational qualifications.
\end{abstract}

Keywords: Locus of control, School teachers, Internal locus of control, External locus of control, Luck.

\section{Introduction}

In the present scenario there is the changing time in every field around the world. With the start of new millennium, societies are engaging in serious and promising educational reforms. One of the key factors in the sere forms is the school teachers. Understanding teachers' perceptions and beliefs is important because teachers, heavily involved in various teaching and learning processes, are practitioners of educational principles and theories (Jia, Eslami \& Burlbaw, 2006)

\section{Locus of control}

There is a concept in the psychological literature known as locus of control that is unfamiliar to most people, even though, once defined, is commonly understood. Locus of control is an individual's belief system regarding the causes of his or her experiences and the factors to which that person attributes success or failure.

This concept is usually divided into two categories: internal and external. If a person has an internal locus of control, that person attributes success to his or her own efforts and abilities. A person who expects to succeed will be more motivated and more likely to learn. A person with an external locus of control, who attributes his or her success to luck or fate, will be less likely to make the effort needed to learn. People with an external locus of control are also more likely to experience anxiety since they believe that they are not in control of their lives. This is not to say, however, that an internal locus of control is "good" and an external locus of control is "bad." There are other variables to be considered, however, psychological research has found that people with a more internal locus of control seem to be better off, e.g. they tend to be more achievement oriented and get better paying jobs.

\section{The Benefits and Drawbacks}

\section{Internal locus of control}

Individuals who have a high internal locus of control tend to believe that they have a high degree of control over what happens in their lives. For example, a person who has a locus of control that is highly internal may believe that their good health is due to a healthy diet and exercise, or that winning a game is due to skill and effort. These individuals tend to see the good and bad things that happen to themselves and others as a result of their own actions or lack of action.

\section{External locus of control}

Individuals who have a locus of control that is primarily external tend to believe that the events in their lives are controlled by external factors like luck, fate, others' behavior or "powerful others." For example, a person with a high degree of external locus of control might believe that their good health is due to genetics or environmental factors, or that winning a game is largely due to lucky events. These individuals tend to see the good and bad things that happen to them and others as being controlled by factors outside of their control. 
Teachers with internal locus of control struggle so as to be able to change the factors which cause their job satisfaction to be low. If they cannot make any change and this situation affects their lives in a negative way, these teachers tend to leave their jobs and transfer to the other jobs by which they will be happier (Czubaj, 2000).

\section{Survey of Literature}

(Anu Singh Lather, 2014) conducted a research on "Component of creativity in relation to locus of control". It was found that 146 students had external locus of control and 98 students were found to have internal locus of control. The students with internal locus of control were found to be higher on Fluency, Elaboration, Flexibility, Figural Response, Norm Referenced Creativity, Criterion Referenced Creativity and Total Creativity. Females were found to be significantly better than males on Originality, Elaboration, Flexibility, Norm Referenced and Criterion Referenced creativity. (Arora, 2017) conducted the research on "Locus of Control and Emotional Intelligence among High and Low Self-Efficacious School Students". Result shows that there is a variation in the level of locus of control and emotional intelligence between high and low selfefficacious students. It is also found that there is a statistically significant gender difference in locus of control and emotional intelligence between high and low self efficacious students. It means that boy and girl school students were significantly differ in their locus of control and emotional intelligence. (Borooah, 2017) conducted the research on "Locus of Control and Academic Achievement of Undergraduate College Students of Guwahati city". The results indicated that there was no significant positive correlation between external locus of control and academic achievement of the students. (Sudha, 2010) conducted a research on "Influence of Locus of Control on Investment Behaviour of Individual Investor". Overall 11 hypotheses were tested. Not only was the data compared in the entirety, it was also compared on the basis of inter role distance, role stagnation, role expectation conflict, role erosion, role overload, role isolation, personal inadequacy, self-role distance, role ambiguity and resource inadequacy. (Igbeneghu, 2017) conducted a research on "The influence of work locus of control on perceived stress of librarians in public universities in south western Nigeri”. Results indicated a significant difference between perceived stress of librarians who have external locus of control and librarians who have internal work locus of control. It was shown that librarians who have external work locus of control (externals) perceived a higher level of stress than librarians who have internal work locus of control (internals). It was concluded from the study that work locus of control of librarians had influence on their perceived stress. (Shannak, 2012) conducted a research on "Factors affecting Work Locus of Control: An Analytical and Comparative Study". The study indicated that a correlation exists between this new variable and work locus of control. Also the study showed that work locus of control for Jordanian employees ranked in the middle of the international norms. The sample scored 47 which is about ten points lower than the extremist Externals in China and ten points higher than the other extreme of Internals in New Zealand. (Robab Besharat, 2018) conducted a research on "A Comparative Study of Rumination, Healthy Locus of Control, and Emotion Regulation in Children of Divorce and Normal Children". According to the results, compared to normal children, children of divorced parents had significantly higher rumination, suppression emotion regulation, and chance and powerful others locus of control; but significantly lower reappraisal emotion regulation and internal locus of control. Rumination, healthy locus of control, and emotion regulation have important role in mental health and adjustment. Because impairment in these scopes is common among children of divorce, it is suggested that the results of the present study be used in designing treatment and care programs for children of divorce. (GÖKALP, 2018) conducted a research on "The Relationship between Irrational Beliefs and Locus of Control of The University Students". According to the results of analyses students hate to fail in most cases. Most of them believed that there is no perfect solution in real life. They tried to consult someone who is more experienced about a particular subject when they make an important decision. (MENTESE, 2018) conducted a research on "The Relationship between Irrational Beliefs and Locus of Control of The University Students". According to the results of analyses students hate to fail in most cases. Most of them believed that there is no perfect solution in real life. They tried to consult someone who is more experienced about a particular subject when they make an important decision. (KORKMAZ, 2018) conducted a research on "Academic Procrastination in Secondary School Students: Examining the Prediction of the Self-Efficacy and Locus of Control". According to findings obtained, academic procrastination behaviors were significantly predicted by self-efficacy and locus of control. The findings were discussed in the literature and suggestions were presented. (Ozan Korkmaz, 2018) conducted a research on " An investigation of self- efficacy, locus of control and academic procrastination as predictors of academic achievement in students diagnosed as gifted and non-gifted". According to 
the results, it can be said that academic procrastination has an important role in the academic achievement of gifted students, whereas self-efficacy, locus of control, and academic procrastination have a significant part to play in the academic achievement of non-gifted students. The comparison of self-efficacy, locus of control, and academic procrastination scores of gifted and non-gifted students indicated that the self-efficacy scores of gifted students were significantly higher than those of the non-gifted. (Deepa, 2018) conducted a research on "A comparative study of self-motivational attributes: self-efficacy, locus of control and goal setting among students pursuing general degree and professional courses". Self-efficacy was positively related to previous grade points and future goal grade points. Factors of locus of control including chance factor and external locus of control mainly contributed to their academic achievement and future goal grade points. Internal locus control does not show any contribution to academic achievement and future goal grade points in this study. (Sayed Shamsaddin Zarin, 2017) conducted a research on "Relationship between Locus of Control with Posttraumatic Growth among Individuals with Spinal Cord Injury". The results suggest that the mean internal LOC scales in spinal cord injured patients with symptoms of PTG is higher. This study found that the LOC in spinal cord injury can affect individuals' health and result in an increased possibility for PTG. (Sarıcam, 2018) conducted a research on "The relationships between positive thinking skills, academic locus of control and grit in adolescents". According to the findings, positive correlation between internal academic locus of control and positive thinking skills was found $(\mathrm{r}=.54)$. A positive correlation was found between the internal academic locus of control and grit at $(\mathrm{r}=.58)$. A positive correlation was found between positive thinking skills and grit $(\mathrm{r}=.61)$. The internal academic locus of control, external academic locus of control and positive thinking skills explain the $50 \%$ of the grit's total variance. Based on this evidence, it can be said that the academic locus of control and positive thinking skills are important predictors for grit. (Azizeh Chalak, 2014) conducted a research on "The Relationship between the Types of Locus of Control and the Academic Achievement of Iranian Online Foreign Language". The participants' grade point averages (GPAs) were the measure of their academic achievement. The t-tests for the independent samples were performed on the data. The findings of this study revealed no significant relationship between LOC and academic achievement. (Angelova, 2016) conducted a research on "Locus of Control and its relationship with some socialdemographic factors". The majority of the participants (472,
77.7\%) indicated an external locus of control. Three of four factors - family status, professional activity, and education - had a significant relationship, and place of residence was the only factor without a significant relationship with the locus of control. (Susan Evans, 2000) conducted a research on "Health locus of control, distress, and utilization of protease inhibitors among HIV-positive men". In addition to physical symptoms, the attribution of health status to chance or fate significantly predicted depressive symptoms, feelings of hopelessness, and recent life stress. Results also demonstrated a significant relationship between strong, positive beliefs in doctors and other health care professionals and PI utilization. The results of this study point to a strong association between beliefs that health status is related to chance or fate and distress. In addition, beliefs in physicians and other health care providers appear to contribute to decisions to initiate PI therapy. D 2000 Elsevier Science Inc. (Hadi Hashemi Razini, 2017) conducted a research on "Relationship between coping strategies and locus of control with the anxiety of death in old people". The results of stepwise regression analysis indicated that avoidance and emotion oriented coping and external locus of control significantly predict death anxiety $(\mathrm{P}<0.01)$. Death anxiety is one of the key factors in the mental health of older adults. With regard to our findings, coping strategies and locus of control have an important role in death anxiety in older adults. Therefore, by designing psychological interventions based on coping strategies and changing locus of control from external to internal, death anxiety among the older adults can be improved. (Gholtash, 2015) conducted a research on "The relationship between happiness, self-control and locus of control". The results of this study indicated that, happiness is positively and significantly related to self-control. Furthermore, selfcontrol was the strongest predictor for happiness. Conclusion: It was also suggested that self-control is positively and significantly related to LOC.

\section{Objectives of the Study}

1. To study the locus of control of teachers working in schools of Rajkot city.

2. To compare the locus of control of teachers of different age group in schools of Rajkot city.

3. To compare the locus of control of married and unmarried teachers working in schools of Rajkot city.

4. To study the locus of control of teachers based on their educational qualification of in schools of Rajkot city. 


\section{Research Methodology}

\begin{tabular}{|l|l|}
\hline Research Type & Descriptive \\
\hline Population & $\begin{array}{l}\text { All The Teachers working in pre- } \\
\text { primary and primary section of } \\
\text { schools in Rajkot }\end{array}$ \\
\hline Sample Size & 103 \\
\hline $\begin{array}{l}\text { Sampling } \\
\text { Method }\end{array}$ & Convenience Sampling \\
\hline Source of Data & $\begin{array}{l}\text { 1. Primary Source by Questionnaire } \\
\text { 2. Secondary Source For literature } \\
\text { Review }\end{array}$ \\
\hline $\begin{array}{l}\text { Data Collection } \\
\text { Instrument }\end{array}$ & $\begin{array}{l}\text { Questionnaire - Locus of control by } \\
\text { Pareek and Purohit (2011) 3 } \\
\text { edition. }\end{array}$ \\
\hline $\begin{array}{l}\text { Tools Used for } \\
\text { Analysis }\end{array}$ & $\begin{array}{l}\text { 3. Charts and Graphs } \\
\text { 4. Correlation, T-test and ANOVA } \\
\text { for testing of hypothesis }\end{array}$ \\
\hline
\end{tabular}

\section{Hypotheses}

$\mathbf{H}_{\mathbf{0} 1}$ : There is no significant correlation between the internal, external and external (Chance) Locus of control of teachers working in schools of Rajkot city w.r.t. age.

\section{Sub-hypotheses}

1. There is no significant Correlation between the internal Locus Of Control of teachers working in schools of Rajkot city with respect to Age.

2. There is no significant Correlation between the External (others) locus of control of teachers working in schools of Rajkot city with respect to Age.

3. There is no significant Correlation between the External (Luck) locus of control of teachers working in schools of Rajkot city with respect to Age.

$\mathbf{H}_{\mathbf{0} 2}$ : There is no significant difference between the internal, external and external (Chance) Locus of Control of teachers working in schools of Rajkot city.

\section{Sub-hypotheses:}

1. There is no significant difference between the internal locus of control of teachers working in schools of Rajkot city with respect to Marital Status.

2. There is no significant difference between the External (others) locus of control of teachers working in schools of Rajkot city with respect to Marital Status.

3. There is no significant difference between the external (Luck) locus of control of teachers working in schools of Rajkot city with respect to Marital Status.

$\mathbf{H}_{\mathbf{0 3}}$ : There is no significant difference between the internal, external and external (Chance) locus of control of teachers working in schools of Rajkot city.

\section{Sub-hypotheses}

1. There is no significant difference between the internal locus of control of teachers working in schools of Rajkot city with respect to Education Qualification.

2. There is no significant difference between the external (others) locus of control of teachers working in schools of Rajkot city with respect to Education Qualification.

3. There is no significant difference between the external (Luck) locus of control of teachers working in schools of Rajkot city with respect to education qualification.

\section{Data Analysis and Interpretation}

The data collected has been processed as suggested in Locus of control chapter by Pareek and Purohit. Three aspects of locus of control are analyzed and coefficient of correlation is calculated for age group of employees and locus of control, later locus of control is analyzed with marital status of employees to determine the difference in locus of control with respect to marital status and finally locus of control is also analyzed with educational qualifications of respondents to determine the difference in locus of control with respect to educational qualification.

$\mathbf{H}_{\mathbf{0 1}}$ : There is no significant correlation between the internal, external and external (Chance) locus of control of teachers working in schools of Rajkot city w.r.t. age.

In hypothesis 1.1, 1.2 and 1.3 correlation test is applied for LOC and age of respondents as we want to find out if there is any significant relationship between age and different aspects of LOC

The following table shows the results:

Table 1: Correlation between age and LOC aspects

\begin{tabular}{|l|c|c|}
\hline LOC aspects & $\begin{array}{c}\text { Coefficient of } \\
\text { Correlation }\end{array}$ & Relationship \\
\hline Internal LOC & 0.126968 & Not Significant \\
\hline External LOC & -0.2278367 & Not Significant \\
\hline $\begin{array}{l}\text { External (Chance) } \\
\text { LOC }\end{array}$ & -0.31126 & Not Significant \\
\hline
\end{tabular}

There is no significant correlation between the different aspects of locus of control of teachers working in schools of Rajkot city with age. However, it has been observed that age increases the external LOC and external (Chance) LOC 
decreases, as revealed by negative correlation between age and these aspects of LOC.

$\mathbf{H}_{\mathbf{0} 2}$ : There is no significant difference between the internal, external and external (Chance) locus of control of teachers working in schools of Rajkot city.

As we want to compare the mean scores of Locus of control with respect to each aspect of married and unmarried teachers working in schools of Rajkot city, we have sub hypotheses with respect to each aspect of locus of control so t- test is applied to each aspect of locus of control to determine locus of control of married and unmarried teachers with each aspect. The summary of hypotheses testing is shown in the following table.

Table 2: Differences between mean LOC for married and unmarried teachers

\begin{tabular}{|l|c|c|c|}
\hline LOC aspects & $\begin{array}{c}\text { Calculated } \\
\text { Value }\end{array}$ & Table Value & Difference \\
\hline Internal LOC & 1.736837698 & 1.984723136 & $\begin{array}{c}\text { Not } \\
\text { Significant }\end{array}$ \\
\hline External LOC & -3.0345 & 1.983731 & Significant \\
\hline $\begin{array}{l}\text { External } \\
\text { (Chance) LOC }\end{array}$ & -3.23039 & 1.985251 & Significant \\
\hline
\end{tabular}

The table above shows that the internal LOC of married and unmarried teachers is not significantly different, but the external and external (chance) LOC of married and unmarried teachers are significantly different. The means revealed that unmarried teachers have higher external and external (chance) LOC as compared to married teachers.

$\mathbf{H}_{\mathbf{0}}$ : There is no significant difference between the internal, external and external (Chance) Locus of Control of teachers working in schools of Rajkot City.

As we want to compare the mean scores of Locus of control with respect to each aspect of teachers with different educational qualifications working in schools of Rajkot city, we have sub hypotheses with respect to each aspect of locus of control so one way Anova is applied to each aspect of locus of control to determine locus of control of teachers with different educational qualifications with each aspect. The summary of hypotheses testing is shown in the following table.

Table 3: Differences between mean LOC for teachers with different educational background.

\begin{tabular}{|l|c|c|c|}
\hline LOC aspects & $\begin{array}{c}\text { Calculated } \\
\text { Value }\end{array}$ & $\begin{array}{c}\text { Table } \\
\text { Value }\end{array}$ & Difference \\
\hline Internal LOC & -3.23039 & 3.087296 & Significant \\
\hline External LOC & 11.40674 & 3.087296 & Significant \\
\hline $\begin{array}{l}\text { External } \\
\text { (Chance) LOC }\end{array}$ & 18.54713 & 3.087296 & Significant \\
\hline
\end{tabular}

The Table above shows the differences are significant for each aspect of LOC w.r.t. educational qualifications of teachers working in schools of Rajkot city. The mean scores revealed that teachers with higher educational qualifications have higher internal LOC.

\section{Findings}

1. It is found that the respondent score high on internal locus of control and lowest on external (Change) LOC.

2. There is no significant correlation between the internal locus of control of teachers working in schools of Rajkot city with respect to Age.

3. There is a significant correlation between the external (others) locus of control of teachers working in schools of Rajkot city with respect to Age.

4. There is no significant correlation between the external (Luck) locus of control of teachers working in schools of Rajkot city with respect to Age.

5. There is no significant difference between the internal locus of control of teachers working in schools of Rajkot city with respect to Marital Status

6. There is no significant difference between the External (Others) locus of control of teachers working in schools of Rajkot city with respect to marital Status

7. There is no significant difference between the external (Luck) locus of control of teachers working in schools of Rajkot city with respect to Marital Status.

8. There is no significant difference between the internal locus of control of teachers working in schools of Rajkot city with respect to education qualification.

9. There is a significant difference between the external (others) locus of control of teachers working in schools of Rajkot city with respect to education qualification.

10. There is no significant difference between the External (Luck) locus of control of teachers working in schools of Rajkot city with respect to Education qualification.

11. The teachers having degree in education is less in number.

\section{Limitations of the Study}

1. The research was limited to Rajkot city only, so the conclusion for other cities cannot be drawn out of it.

2. The questionnaires were filled by teachers in presence of their superior, so there can be possibility of the influence of their superiors.

3. The teachers were in heavy workload so some the questionnaires filled by the teachers who were in stress cannot be called reasonable.

4. In the current sample all the respondents were females.

5. The responses received to the questionnaire were 103 only because of time constraint. 


\section{Conclusion}

This study is the first study done on the Locus of control of teachers of Rajkot city. From the research it was found that the internal locus of control of Gujarati medium teachers are less than English medium teachers. The study also says that with the increase in age there is less effect on internal locus but more effect on external locus. Research says that when people have high internal locus of control they take charge of the events happening in their life positively. Here if the management makes the environment such that people feel high internal locus of control the teachers will be more motivated to work.

\section{Source of Funding}

None.

\section{Conflict of Interest}

None.

\section{References}

1. Angelova, V. Locus of control and its relationship with some social-demographic factors. Psychol Thought. 2016;9(2)1-11.

2. Lather AS, Jain S, Shukila AD. Components of Creativity in relation to Locus of Control. J Res Humanit Soc Sci. 2014;2(10):48-61.

3. Roy B, Arora A. Locus of control and emotional intelligence among high and low self-efficacious school students. The Int $J$ Indian Psychol. 2017;4(4):19-24.

4. Chalak A, Nasri N, Tabrizi HH. The relationship between the types of locus of control and the academic achievement of iranian online foreign language learners. Cypriot J Educ Sci. 2014;9(1):50-6

5. Choudhury SA Borooah P. Locus of control and academic achievement of undergraduate college students of Guwahati City. Int J Humanit Soc Sci Invention. 2017;6(4):67-70.

6. Czubaj, Anne C. Maintaining teacher motivation. Educ. 2000;116(3):372-8

7. Deepa MN, Pallavi P. A comparative study of selfmotivational attributes: self-efficacy, locus of control and goal setting among students pursuing general degree and professional courses. Int J Sci Res. 2018;7(3)219-20.

8. Ramezani SG, Gholtash A. The relationship between happiness, self-control and locus of control. Int J Educ Psychol Res.2015;1(2):100-4.
9. Gokalp M. The relationship between irrational beliefs and locus of control of the university. The Turk Online J Educ Technol.2018;464-76.

10. Razini HH, Juybari SB, Ramshini M. Relationship between coping strategies and locus of control with the anxiety of death in old people. Iran J Ageing. 2017;12(2): 232-41.

11. Igbeneghu, BI. The Influence of work locus of control on perceived stress of librarians in public universities in South Western Nigeria. Inte J Adv Sci 2017;4(8):16-25.

12. Jia Y, Eslami ZR, Burlbaw LM. ESL teachers' perceptions and factors influencing their use of classroom-based reading assessment. Bilingual Res J. 2006;29(2):459-82.

13. Korkmaz O. Academic procrastination in secondary school students: Examining the prediction of the self-efficacy and locus of control. Int J Soc Res. 2018;7(1):19-35.

14. Mentese AG. The relationship between irrational beliefs and locus of control of the university students. Int Teacher Educ Conf. 2018;564-76.

15. Korkmaz O, Ilhan, Tahsin, Bardakci, Salih. An investigation of self-efficacy, locus of control, and academic procrastination as predictors of academic achievement in students diagnosed as gifted and non-gifted. Eur J Educ Stud. 2018;4(7):173-92.

16. Robab Besharat, Ebhrahim SA, Mohammadian A. A comparative study of rumination, healthy locus of control, and emotion regulation in children of divorce and normal children. Pract Clin Psychol. 2018;6(4):207-14.

17. Sarıcam H, Çelik I. The relationships between positive thinking skills, academic locus of control and grit in adolescents. Universal J Educ Res. 2018;6(3):392-8.

18. Zarin SS, Mohammad SK, Foroughan M, Hosseini MA, Bakhshi E Mohammad K. Relationship between Locus of control with posttraumatic growth among individuals with spinal cord injury. J Modern Rehabil. 2017;11(2):109-18.

19. Shannak, RO, Al-Taher A. Factors affecting work locus of control: an analytical and comparative. Jordan J Business Administration. 2012;8(2):483-9.

20. Sudha DR. Influence of locus of control on investment. Vidwat - The Indian Manag. 2010;1-50.

21. Evans S, Ferrando SJ, Rabkin JG, Fishman B. Health locus of control, distress, and utilization of protease inhibitors among HIV-positive men. J Psychosomc Res. 2000;49(2):157-62.

22. Aulia Y, Laksamana A, Basuki. Locus of control and the acceptance of dysfunctional audit behavior in a review of philosophy Semar. Int J Sci Res Publications. 2017;7(11):26469.

How to cite: Achhnani B, Amareliya A. Locus of control of school teachers. J Manag Res Anal. 2020;7(1):40-5. 